\title{
28. TRACE FOSSILS AND ICHNOFABRIC IN TRIASSIC SEDIMENTS FROM CORES RECOVERED ON LEG 1221
}

\author{
M. L. Droser ${ }^{2}$ and S. O'Connell ${ }^{3}$
}

\begin{abstract}
Combined ichnofabric and sedimentological facies analyses were undertaken in Triassic cores from Ocean Drilling Program Sites 759, 760, 761, and 764 on the Wombat Plateau, northwest Australia, to determine the depositional environment and ichnological signature of these Upper Triassic and shallow-water/marginal marine sediments. Six sedimentary facies were identified in a mixed siliciclastic and carbonate system. Distinct ichnological signatures, in terms of discrete trace fossils and the ichnofabric, can easily be determined for terrigenous clastic strata as well as for open-marine carbonate sediments. Brackish water facies are characterized by low ichnofabric indexes and low trace fossil diversity. Chondrites is the most common trace fossil in prodelta deposits, although these strata are commonly not bioturbated. Sandstones deposited in high-energy nearshore settings are also not well-bioturbated, whereas open-shelf strata are completely bioturbated. Nearshore coarse-grained facies are more problematic.
\end{abstract}

\section{INTRODUCTION}

In core studies, trace fossils provide important paleoecological and paleoenvironmental information. Most ichnological work on cores has concentrated on discrete trace fossils in deep-sea cores (e.g., Ekdale, 1977, 1978, 1980; Fütterer, 1984; Wetzel, 1987). Few studies have been conducted on trace fossils in cores of shallow-water or even shelf sediments (but see Beynon et al., 1988, and Wightman et al., 1987). Discrete trace fossils provide important evidence for the composition and behavior of macrofauna; however, they cannot be used to determine the extent of mixing. In addition, much of the ichnological record consists of "mottled bedding," in which discrete trace fossils cannot be identified. Ichnofabric is sedimentary rock fabric that results from biogenic reworking (Ekdale et al., 1984). Thus, ichnofabric records the total extent of preserved bioturbation, including discrete trace fossils as well as mottled bedding. Studies of ichnofabric can be used to document the amount of mixing as well as for paleoenvironmental analysis. The previous study of ichnofabric in Cretaceous and Tertiary sediments recovered on Ocean Drilling Program (ODP) Leg 119 demonstrated the utility of examining ichnofabric in cores (Droser and Bottjer, 1991). These sediments were, however, primarily from the deep sea with only a thin section of outer-shelf sediments. In contrast, cores recovered during Leg 122 include a thick sequence of Upper Triassic shallow-water/marginal marine sediments. No record of bioturbation in Triassic terrigenous, clastic, marginal marine sediment cores has previously been published. Thus, these Leg 122 sediments provide a unique opportunity to document ichnofabric and discrete trace fossils in shallowwater sediments of Triassic age.

This paper presents an integrated study of the Upper Triassic sedimentary facies, ichnofabric indexes, and discrete trace fossils recovered at four sites on the Wombat Plateau,

\footnotetext{
${ }^{1}$ von Rad, U., Haq, B. U., et al., 1992. Proc. ODP, Sci. Results, 122 : College Station, TX (Ocean Drilling Program).

2 Department of Earth Sciences, University of California, Riverside, CA 92521, U.S.A.

${ }^{3}$ Department of Earth and Environmental Sciences, Wesleyan University, Middletown, CT 06457, U.S.A.
}

northwest Australia. These features reflect changing depositional environments of the southern Tethys margin during the Upper Triassic.

The northwestern Australian margin formed during the Mesozoic as part of the southern margin of Tethys and thus is one of the oldest rifted continental margins (preserved) in the world (Sengör, 1985). The Exmouth Plateau (Fig. 1A), which is part of this margin, consists of rifted and deeply subsided continental crust overlain by an 8-9-km-thick sedimentary sequence (Exon and Willcox, 1978). The Wombat Plateau, a small subplateau, is located along the northern edge of the Exmouth Plateau and is separated from it by a deep halfgraben.

Lying at approximately $2000 \mathrm{~m}$ water depth, the Wombat Plateau covers a $5800-\mathrm{km}^{2}$ area, with an upper surface that slopes gently northward (Fig. 1B). A four-site transect was drilled across the Wombat Plateau on the northwest Australian margin during Leg 122 (Fig. 1). At these four sites an almost continuous, 900-m-thick, Upper Triassic (Carnian-Rhaetian) sequence was recovered underlying a thin veneer of Cretaceous and Cenozoic sediments. The Triassic sediments consist of about $30 \%$ carbonates and $70 \%$ low-energy paralic to fluviodeltaic sediments (Haq, von Rad, O’Connell, et al., 1990).

\section{METHODS}

Sedimentary facies and ichnofabric indexes were distinguished by visual inspection of the archive half of the cores Although the ODP sedimentary classification scheme is used (see "Explanatory Notes" in Haq, von Rad, O'Connell, et al., 1990), the facies identified here are not identical to those distinguished during Leg 122 or to facies distinguished in other sedimentological papers in this volume (e.g., Borella et al.; Dumont; Ito et al.; Röhl et al.; and Sarti et al.). All of the cores discussed in this paper were reexamined during a week-long study at the Gulf Coast Repository. This allowed us the advantage of placing selected cores from all the sites next to each other and thereby distinguishing the facies described in this paper.

In some intervals the cores were too disrupted by coring disturbance (e.g., Cores $122-760 \mathrm{~A}-10 \mathrm{X}$ to $-23 \mathrm{X}$ ) or recovery was too poor (e.g., Cores $122-764 \mathrm{~B}-8 \mathrm{R}$ to $-30 \mathrm{R}$ ) to determine either the sedimentary facies or ichnofabric indexes. 

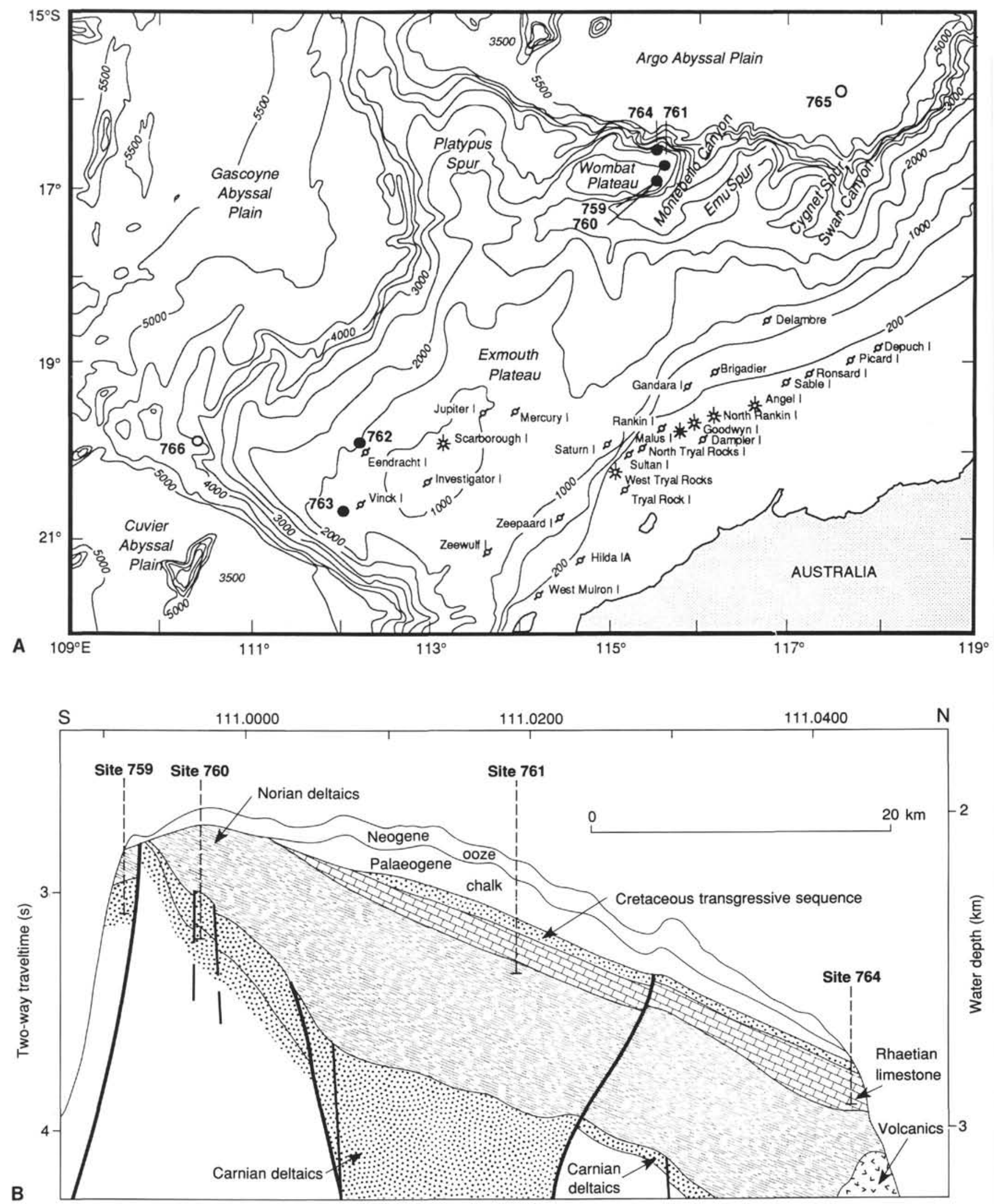

Figure 1. A. Bathymetric map of the northwest Australian margin showing the location of Sites 759-765 drilled during Legs 122 and 123 and commercial petroleum exploration wells (standard industry symbols) (modified from Haq, von Rad, O'Connell, et al., 1990). B. Interpreted multichannel seismic line (Rig Seismic 56-13) showing location of Sites 759-761 and 764 (von Rad et al., 1989). 
Bioturbation disrupts original physical sedimentary structures. To evaluate the extent of bioturbation, Droser and Bottjer (1986) established a classification scheme of ichnofabric based on the amount of original physical sedimentary structures disrupted by biogenic reworking, from no bioturbation (ichnofabric index [ii] 1) to complete homogenization (ii6), which has been adapted for use in core studies (Droser and Bottjer, 1991). These indexes can be represented by schematic diagrams, or "flash cards," such as those in Droser and Bottjer (1986) for thin-bedded shelf carbonates or those presented in Figure 2 that have been developed for cores. These flash cards can be used to evaluate the extent of bioturbation in cores. This methodology is analogous to the use of the charts found in Terry and Chilingar (1955) for estimating percent composition of rocks and sediments. Sections are logged for ichnofabric in a manner similar to the continuous logging of strata for such properties as rock color or lithology (e.g., Fig. 3; Droser and Bottjer, 1988; Bjerstedt and Erickson, 1989).

This method eliminates the need for such very subjective terms as "weakly bioturbated," "moderately bioturbated," and "commonly bioturbated" and standardizes the description of the extent of bioturbation, which can then be used for comparison of the extent of bioturbation between the same facies, or between beds of different facies.

\section{FACIES AND ICHNOLOGY}

Six sedimentary facies were distinguished on the basis of grain size, composition, sedimentary structures, color, and distinct ichnological signatures (Tables 1 and 2). Body fossils are rare in all facies except Facies V (see below). Not all sedimentological lithologies are equally well preserved in cores. For example, sands and coarse-grained carbonate (packstone, wackestone, grainstone) sediments are poorly preserved and commonly not recovered. Thus, the amount of ichnofabric index data recorded from any given facies is not necessarily a direct indication of the amount of that facies represented in these cores. In addition, in some facies, such as packstone, ichnofabric is commonly difficult to discern in a single core width. Where a major discrepancy exists between the total amount of a facies represented and the meterage for ichnofabric data, the approximate total of the facies is included.

\section{Facies I}

Facies I (Pl. 1, Figs. 1 and 2) is the most common facies represented in these cores, comprising nearly half (over 122 $\mathrm{m})$ of the examined material. It consists of dark, commonly black, thinly to wispy bedded (mm), silty claystone, clayey siltstone, and rare sandstone. Sedimentary structures include parallel and cross lamination. Pyrite, glauconite, and rare plant debris are present. In general, evidence of high-energy conditions is lacking. Body fossils are rare. Calcium carbonate $\left(\mathrm{CaCO}_{3}\right)$ content ranges from $0.2 \%$ to $40.4 \%$ but is mostly $<2.5 \%$. Total organic carbon (TOC) contents are generally between $1 \%$ and $2 \%$, but range from $0.04 \%$ to $2.66 \%$, depending upon the proximity to intervals with plant debris.

For the most part, this facies is not well bioturbated. Ichnofabric index 1 was recorded from over $50 \%$ of the facies, and ichnofabric index 2 from over 20\% (Fig. 3A). Trace fossil diversity is also low. The most common trace fossil in this facies is Teichichnus, a retrusive burrow with a vertical sequence of commonly concave-up crescentic laminae that reflect deposit-feeding activities (e.g., Beynon et al., 1988; Häntzchel, 1975). Chondrites, Planolites, and Skolithos are also present (Table 2). Chondrites and Planolites also reflect deposit-feeding activities. Planolites is commonly smaller
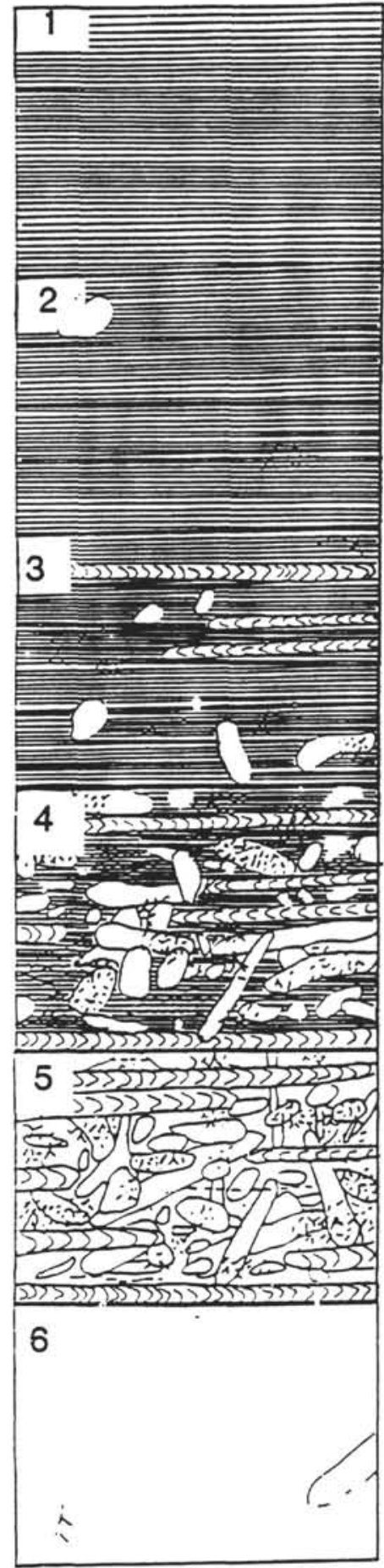

Figure 2. Schematic diagrams for ichnofabric indexes 1 through 6 . Ichnofabric indexes are defined (Droser and Bottjer, 1986) as follows: 1 = no bioturbation recorded, all original sedimentary structures; 2 = discrete, isolated trace fossils, with up to $10 \%$ of original bedding disturbed; 3 = approximately $10 \%-40 \%$ of original bedding disturbed, with burrows generally isolated, but locally overlapping; 4 = last vestiges of bedding discernible, approximately $40 \%-60 \%$ disturbed, and burrows overlap and are not always well defined; $5=$ bedding is completely disturbed, but burrows are still discrete in places and the fabric is not mixed; and $6=$ sediment is nearly or totally homogenized, with discrete trace fossils no longer visible (after Droser and Bottjer, 1991). 

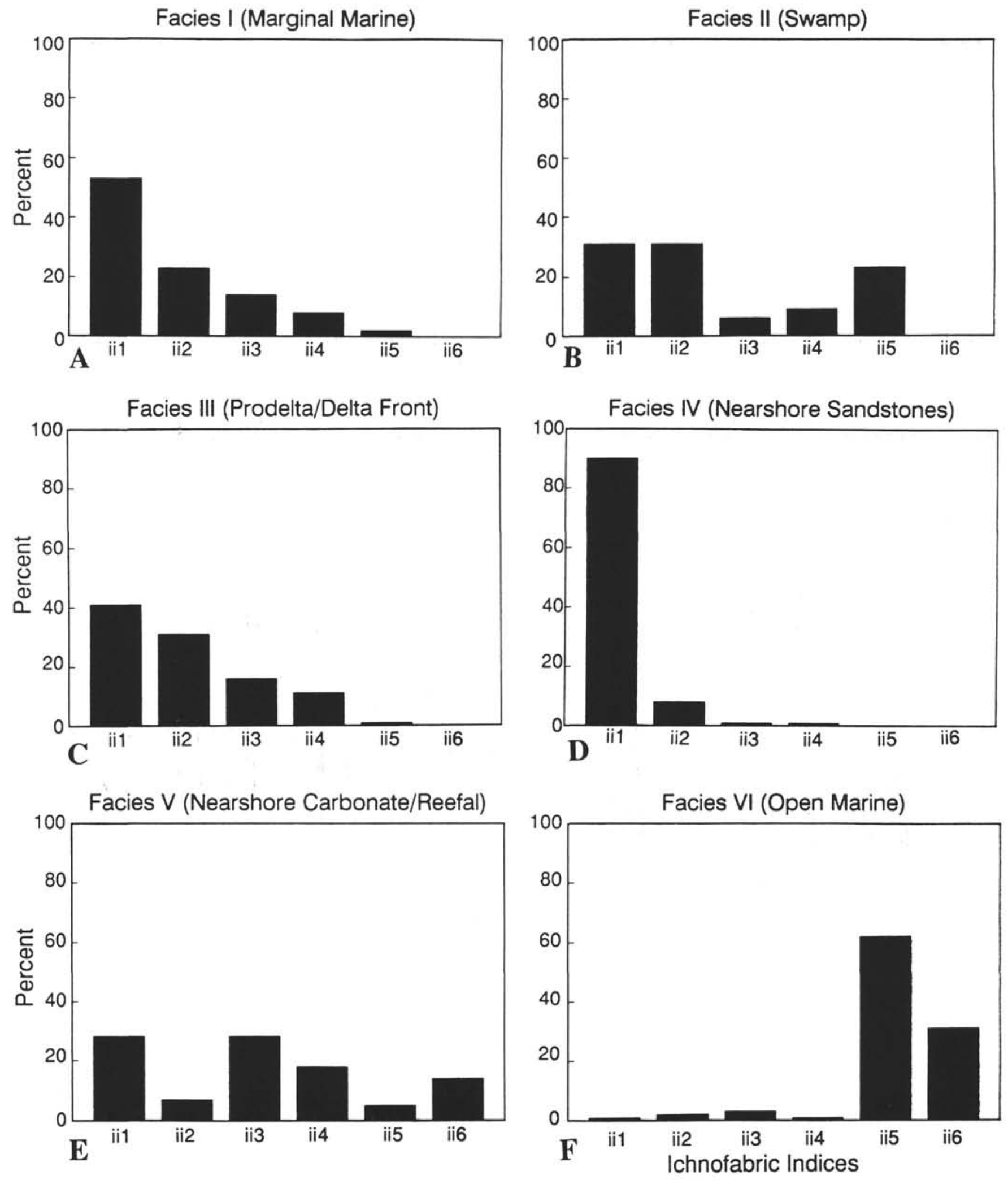

Figure 3. Distribution of ichnofabric indexes for each of the six environmental settings as graphically shown through ichnograms A through F. 
Table 1. Dominant characteristics of sedimentological facies.

\begin{tabular}{|c|c|c|c|c|c|c|c|}
\hline Facies & Composition & $\begin{array}{l}\text { Sedimentary } \\
\text { structures }\end{array}$ & Color & $\begin{array}{l}\% \mathrm{CaCO}_{3} \\
\text { range } \\
\text { / average }\end{array}$ & $\begin{array}{l}\% \text { TOC } \\
\text { range } \\
\text { / average }\end{array}$ & $\begin{array}{l}\text { Ichnofabric } \\
\text { index relative } \\
\text { abundance }\end{array}$ & Comments \\
\hline I & $\begin{array}{l}\text { Silty claystone, clayey } \\
\text { siltstone }\end{array}$ & $\begin{array}{l}\text { Parallel and cross } \\
\text { lamination, very } \\
\text { thin discontinous } \\
\text { beds }\end{array}$ & $\begin{array}{l}\text { Dark gray, } \\
\text { black }\end{array}$ & $\begin{array}{l}0.2-40.4 \\
l<2.5\end{array}$ & $\begin{array}{l}0.04-2.66 \\
/ 1-2\end{array}$ & ii1, ii2, ii3, ii4 & Pyrite and glauconite present \\
\hline II & $\begin{array}{l}\text { Claystone, siltstone, } \\
\text { sandstone, coal, and } \\
\text { other plant material }\end{array}$ & $\begin{array}{l}\text { Parallel and cross } \\
\text { lamination, root } \\
\text { structures }\end{array}$ & $\begin{array}{l}\text { Very dark gray, } \\
\text { black }\end{array}$ & $\begin{array}{l}0.3-12.1 \\
/<3.0\end{array}$ & $0.20-2.26$ & iil, ii2, ii5, ii4 & Pyrite and siderite common \\
\hline III & $\begin{array}{l}\text { Claystone and siltstone, } \\
\text { sandstone (rare) }\end{array}$ & $\begin{array}{l}\text { Well-bedded load } \\
\text { casts and flame } \\
\text { structures }\end{array}$ & $\begin{array}{l}\text { Dark gray, very } \\
\text { dark gray }\end{array}$ & $\begin{array}{l}0.6-31.0 \\
/<3.0\end{array}$ & $\begin{array}{l}0.08-3.42 \\
/ 0.8-2.0\end{array}$ & ii1, ii2, ii3, ii4 & \\
\hline IV & $\begin{array}{l}\text { Sandstone with } \\
\text { calcareous and silica } \\
\text { cement }\end{array}$ & $\begin{array}{l}\text { Laminated and } \\
\text { bedded }\end{array}$ & $\begin{array}{l}\text { Dark green gray } \\
\text { to very dark } \\
\text { gray }\end{array}$ & $<0.3$ & $0.05-1.49$ & ii1, ii2 & $\begin{array}{l}\text { Glauconite, quartz, feldspar, } \\
\text { and plant material present }\end{array}$ \\
\hline v & $\begin{array}{l}\text { Wackestone, packstone, } \\
\text { grainstone, boundstone } \\
\text { with carbonate } \\
\text { mudstone }\end{array}$ & & $\begin{array}{l}\text { White, very } \\
\text { pale brown, } \\
\text { gray }\end{array}$ & $\begin{array}{l}84.2-99.1 \\
190\end{array}$ & $\begin{array}{l}\text { Below } \\
\text { detection }\end{array}$ & iil, ii3, ii4, ii6 & $\begin{array}{l}\text { Corals, mollusks, bryozoans, } \\
\text { algae, crinoids, brachiopods }\end{array}$ \\
\hline VI & $\begin{array}{l}\text { Clayey carbonate } \\
\text { mudstone }\end{array}$ & Parallel laminations & $\begin{array}{l}\text { Light gray to } \\
\text { very dark } \\
\text { gray }\end{array}$ & $57.9-65.6$ & $0.43-0.23$ & iis, ii6 & Crinoid and mollusk fragments \\
\hline
\end{tabular}

Note: TOC $=$ total organic content and $\mathrm{ii}=$ ichnofabric index.

than usual in these cores, $<1 \mathrm{~cm}$ and commonly under $5 \mathrm{~mm}$ in diameter. Skolithos is interpreted as a burrow of a suspension feeder. Depth of bioturbation measured from Skolithos burrows is rarely up to $10 \mathrm{~cm}$. This facies is present at all sites but is most common in Site 760. This facies grades into Facies II and Facies III.

\section{Facies II}

Facies II (Pl. 1, Fig. 2) consists of claystone, siltstone, and sandstone. Sedimentary structures include parallel and crosslamination. It is the second most common facies with ichnofabric indexes recorded from approximately $6340 \mathrm{~cm}$. Black mudstone is common. Coal beds, roots, and plant material are abundant. Pyrite and siderite are present. It is most common in Cores $122-760 \mathrm{~A}-31 \mathrm{X}$ to $-38 \mathrm{X}$. Although recovery in these extended core barrel cores was roughly $67 \%$, the sediments were highly disturbed. Burrows are commonly not distinct, but they do include Chondrites, Skolithos, and Planolites (Table 2). Burrows are small $(<1 \mathrm{~cm})$. Bioturbation related to plant roots is common. Ichnofabric in this facies is variable, in large part because of root mottling. Ichnofabric resulting solely from animal activities is reflected by high values of ii2 in addition to iil (Fig. 3B). The nearly $25 \%$ of the strata with recorded ii5 is plant-root mottled. TOC ranges from 0.20 to $2.26 \%$, with the values measured highly dependent upon the presence of plant material. $\mathrm{CaCO}_{3}$ values lie between $0.25 \%$ and $12.08 \%$, with most being $<3 \%$.

\section{Facies III}

Facies III (Pl. 1, Figs. 3 and 4) consists of well-bedded claystone and siltstone with parallel and cross stratification. Sandstone with minor load casts and flame structures is also present. The facies is not well bioturbated; ichnofabric index 1 was recorded in $40 \%$ of the logged sediments (Fig. 3C). Chondrites is the most common trace fossil in this facies; Planolites and Skolithos occur very rarely. Thus Chondrites is responsible for the presence of ii2 through ii5. Chondrites occurs commonly in distinct beds and is densely packed (PI. 1, Fig. 4). TOC ranges from $0.08 \%$ to $3.42 \%$, with most values between $0.8 \%$ and $2.0 \%$. Calcium carbonate percentages are highly variable $(0.58 \%-31 \%)$, but most are $<3 \%$.

\section{Facies IV}

Facies IV includes laminated and bedded sandstone with calcareous and silica cement. Glauconite as well as quartz, feldspar, and plant material are present. Ichnofabric indexes were recorded for $1022 \mathrm{~cm}$. This is most probably a small percentage of the actual sandstone in this sedimentary sequence. Sandstone is poorly recovered in ODP cores. In addition, drilling disturbance destroyed most ichnofabric that may have been present. Most of the sandstone is plant rich and not bioturbated (Fig. 3D). TOC ranges from $0.05 \%$ to $1.49 \%$ and $\mathrm{CaCO}_{3}$ values are $<0.25 \%$. It is most common in Cores 122-759B-16R and -23R and in Cores 122-760A-28X and 122-760B-22X.

\section{Facies V}

Facies V (Pl. 2) consists of wackestone, boundstone, packstone, and grainstone with interbedded carbonate mudstone. Common solitary corals as well as colonial corals and mollusks (particularly bivalves) are present. Bryozoans and algae are also present with crinoid and brachiopods. In Site 764 , colonial scleractinians are more common. Solitary corals are more common in thinner or spotty occurrences of this facies. Oolites are locally common. Tempestites are also present. Details of the microfacies and paleoenvironments are

Table 2. Distribution of trace fossils in facies.

\begin{tabular}{|c|c|c|c|c|c|c|}
\hline & Zoophycos & Teichichnus & Chondrites & Skolithos & Asterosoma & Planolites \\
\hline Facies I & & $\mathrm{x}$ & $x$ & $\mathrm{x}$ & & $x$ \\
\hline Facies II & & & $\mathrm{x}$ & $\mathrm{x}$ & & $x$ \\
\hline Facies III & & & $\mathrm{x}$ & & & \\
\hline Facies IV & & & & & & $x$ \\
\hline Facies V & & & & $\mathrm{x}$ & & $\mathrm{x}$ \\
\hline Facies VI & $\mathrm{x}$ & $\mathrm{x}$ & & $\mathrm{x}$ & $\mathrm{x}$ & $\mathrm{x}$ \\
\hline
\end{tabular}


discussed by Röhl et al. (this volume). This facies is present in all sites but is most common in Site 764 .

Discrete traces are difficult to identify in the coarse-grained sediment. Ichnofabric indexes were recorded from nearly $2000 \mathrm{~cm}$, less than half of the recovered portion of this facies, which is a small fraction of what was actually penetrated. Skolithos and Planolites are present, but other trace fossils are difficult to identify. Ichnofabric indexes are unevenly distributed, probably reflecting the coarse-grained nature and the poor preservation of this facies. In addition, in outcrop studies, the recognition of lateral facies relationships and differential weathering aid in the recognition of bioturbated coarse-grained carbonate facies. In core studies we do not have these advantages. Organic carbon is generally below detection.

\section{Facies VI}

Facies VI (PI. 1, Fig. 5) consists of bioturbated carbonate claystone and ooze with variable amounts of carbonate and terrigenous clastic mudstone and grades into Facies V. Ichnofabric data was collected from $2254 \mathrm{~cm}$ of this facies. Minor siltstone is present. In Sections 122-764B-31R-3 through -31R$\mathrm{CC}$, there is less carbonate $(60 \%-65 \%)$. No primary physical sedimentary structures were observed.

The fabric commonly consists of mottled bedding (Pl. 1, Fig. 5). Discrete trace fossils are best preserved when the carbonate fraction is lower. Discrete trace fossils include Zoophycos, Asterosoma, Skolithos, Planolites, Teichichnus, Rosselia, and Paleophycus (Table 2).

\section{DISCUSSION}

Discrete trace fossils, ichnofabric, and sedimentary structures can be used to interpret paleoecology and paleoenvironmental variables such as oxygen levels, energy, and salinity. No given trace fossil can be used to indicate specific depth or environmental conditions; however, when combined with ichnofabric index data and sedimentary structures, and when taken as associations, trace fossils and ichnofabric can be used to interpret environmental factors.

The sediments examined from Sites 759, 760, 761, and 764 reflect deposition in a shallow marginal marine/swamp environment to fully open marine in a mixed terrigenous clastic and carbonate system. In these cores trace fossil diversity is low in all but Facies VI.

In Facies I and II diversity of trace fossils is low and the extent of bioturbation is low. In general, these trace fossils fall into the Cruziana and/or Skolithos ichnofacies of Seilacher (1957). Sedimentological and ichnological data indicate that Facies I and II most likely reflect deposition in a brackish water/marginal marine setting.

Brackish water environments are highly variable, but generalizations can be made with respect to ecological systems, which include the following, as summarized in Ekdale et al. (1984): (1) brackish water settings generally are reduced in species numbers with respect to both fresh and fully marine species; (2) brackish water faunas consist of a more impoverished marine fauna rather than of freshwater faunas; (3) infaunal organisms are more abundant than epifaunal organisms in low-salinity waters; and (4) many marine species display a size reduction of individuals with decreasing salinity. These characteristics are similar to those observed in Facies I and II. Facies I and II are characterized by low trace fossil diversity and limited extent of bioturbation, with iil constituting approximately $50 \%$ in each (Fig. 3).

Other trace fossil studies of brackish water settings also indicate a limited extent of bioturbation (e.g., Beynon et al., 1988). The low ichnodiversity and lack of extensive bioturba- tion and the trace fossil assemblage of Teichichnus, Chondrites, Skolithos, and Planolites representing simple horizontal or vertical structures characteristic of both the Skolithos and Cruziana ichnofacies is consistent with a brackish water setting. Burrows are generally smaller than their open-marine counterparts and simple and either horizontal or vertical, unlike the larger and more complex burrows that are present in open-marine facies or even in tidal flat sediments. Fully marine trace fossils such as Zoophycos are not present in these facies. The additional evidence for a brackish water environment include (1) the lack of evidence of high-energy regimes, (2) the presence of laminated or thinly bedded heterolithic sediments and (3) the lack of body fossils (Wightman et al., 1987; Beynon et al., 1988).

Facies I grades into Facies II, which probably represents an even shallower, possibly swampy environment, as indicated by the abundance of plant material, coal seams, root structures, and rare discrete trace fossils including Planolites and Skolithos. Teichichnus is rare.

The fine-grained, well-bedded sediments with load casts in Facies III indicate rapid sedimentation. Such sediments may be prodelta/delta front deposits. Prodelta deposits are the most seaward environment of a prograding delta. Like most deltaic deposits, they show coarsening-upward sequences and differ in being finer grained, with most deposition occurring from suspension. Because deposition is from suspension, the most common sedimentary structure is parallel lamination. Deposition is nonetheless rapid and may result in the formation of load casts and other soft sediment deformation structures. Delta front deposits are the slightly landward equivalent of prodelta deposits and differ only in being coarser grained. Sediments from these two environments can be interbedded as sediment supply, sea level, and subsidence rates fluctuate.

The presence of Chondrites as the only common trace fossil may indicate a prodelta/delta front into a low oxygen setting (e.g., Byers and Larson, 1979).

Facies IV, which consists primarily of sandstones, also is not well bioturbated. This may be because of the high-energy setting of this lithology (e.g., beach setting). Here, ichnofabric index 1 constitutes $90 \%$ recorded from the facies.

Discrete trace fossils and ichnofabric is not well preserved in coarse-grained facies; thus, in Facies V, the ichnological record is variable. Facies V reflects a full-marine, shallowwater carbonate system with sporadic reefs and oolite shoals as well as shallow water, perhaps lagoonal, muddier wackestone settings. The details of the microfacies and paleoenvironments are discussed by Röhl et al. (this volume).

In contrast to all of the above facies, Facies VI is completely bioturbated with open-marine facies that contain seven common discrete trace fossils. Zoophycos, Asterosoma, and Rosselia are common open-marine trace fossils and are more complex than those that occur in other facies.

\section{CONCLUSION}

Assemblages of discrete trace fossils have long been used to aid in the delineation of sedimentary environments and in the recognition of macrofauna behavior and composition. Results from this study suggest that facies also have distinct ichnofabric signatures (Fig. 3). For example, stressed environments, either from low oxygen, variable salinity, or highenergy conditions, generally have a high percentage of iil (e.g., marginal marine and nearshore sandstone facies). Ichnofabric distribution within a facies can be graphically illustrated on an ichnofabric histogram ("ichnogram"). These ichnograms can then be used to fingerprint facies further. Predictably, coarse-grained facies are not as easily characterized by ichnofabric and discrete trace fossils in core studies. 


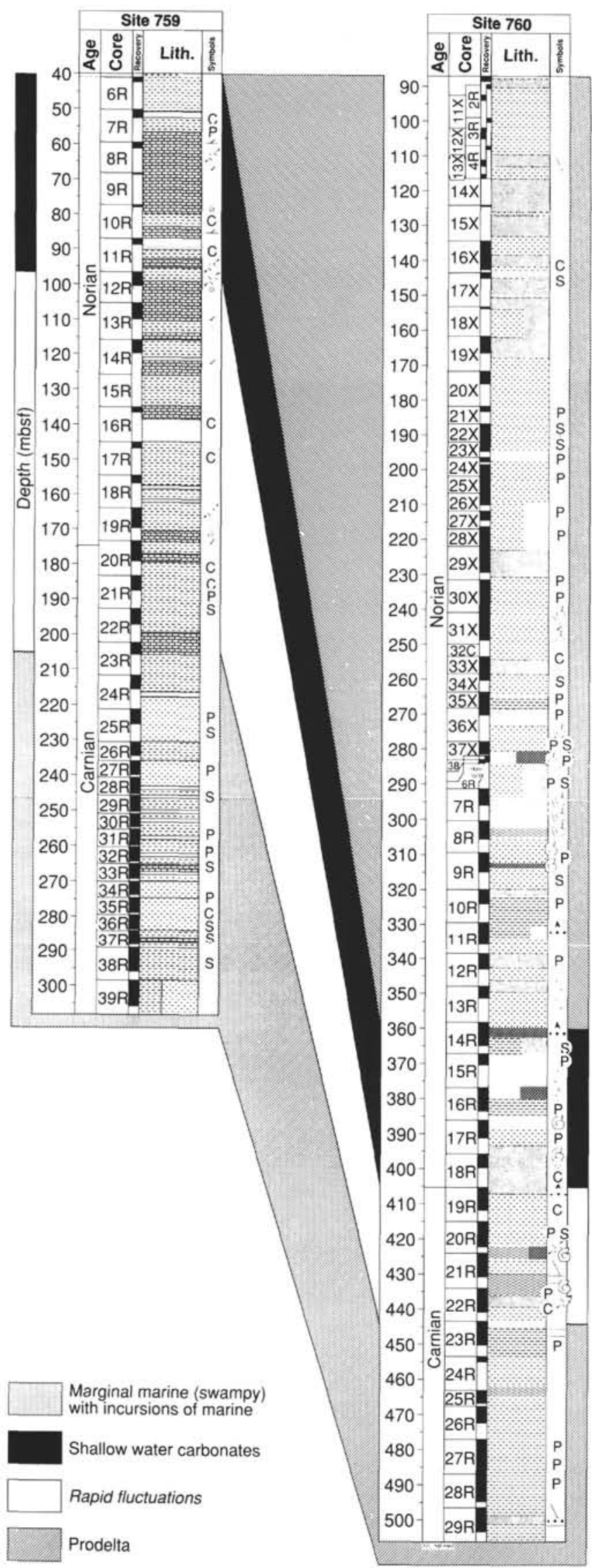

Figure 4. Correlation of facies described from Sites 759 and 760 based on sedimentological and ichnological characteristics.
Ichnofabric distributions and discrete trace fossils (Table 2) can be used in combination to characterize facies in terms of paleoenvironmental biotic factors. Sedimentological and ichnological data as well as facies relationships can then be used to construct a large-scale facies relationships among cores (e.g., Figs. 4 and 5).

\section{ACKNOWLEDGMENTS}

Our thanks to the staff of the Gulf Coast Repository. Funding was provided to MLD by USSAC-NSF EAR \#8915858 and to SOC by USSAC-NSF EAR \#20373. Acknowledgment is also made by MLD to the Petroleum Research Fund of the American Chemical Society for support of this research.

\section{REFERENCES}

Beynon, B. M., Pemberton, S. G., Bell, D. D., and Logan, C. A., 1988. Environmental implications of ichnofossils from the Lower Cretaceous Grand Rapids Formation, Cold Lake Oil Sands Deposit. In James, D. P., and Leckie, D. A. (Eds.), Sequences, Stratigraphy, Surface and Subsurface. Mem.-Can. Soc. Pet. Geol., 15:275-290.

Bjerstedt, T. W., and Erickson, J. M., 1989. Trace fossils and bioturbation in peritidal facies of the Potsdam-Theresa Formations (Cambrian-Ordovician), northwest Adirondacks. Palaios, 4:203224.

Byers, C. W., and Larson, D. W., 1979. Paleoenvironments of Mowry Shale (Lower Cretaceous), western and central Wyoming. AAPG Bull., 63:354-375.

Droser, M. L., and Bottjer, D. J., 1986. A semiquantitative field classification of ichnofabric. J. Sediment. Petrol., 56:558-559.

, 1988. Trends in depth and extent of bioturbation in Cambrian carbonate marine environments, western United States. Geology, 16:233-236.

1991. Trace fossils and ichnofabric in Leg 119 cores. In Barron, J., Larsen, B., et al., Proc. ODP, Sci. Results, 119: College Station, TX (Ocean Drilling Program), 635-664.

Ekdale, A. A., 1977. Abyssal trace fossils in worldwide Deep Sea Drilling Project cores. In Crimes, T. P., and Harper, J. C. (Eds.), Trace Fossils 2. Geol. J. Spec. Issue, Seel House Press, 9:163182.

1978. Trace fossils in Leg $42 \mathrm{~A}$ cores. In Hsü, K., Montadert, L., et al., Init. Repts. DSDP, 42, Pt. 1: Washington (U.S. Govt. Printing Office), 821-827.

1980. Trace fossils in Deep Sea Drilling Project Leg 58 cores. In Klein, G. deV., Kobayashi, K., et al., Init. Repts. DSDP, 58: Washington (U.S. Govt. Printing Office), 601-606.

Ekdale, A. A., Bromley, R. G., and Pemberton, S. G. (Eds.), 1984. Ichnology: Trace Fossils in Sedimentology and Stratigraphy. SEPM Short Course, No. 15.

Exon, N. F., and Willcox, J. B., 1978. Geology and petroleum potential of the Exmouth Plateau area, off western Australia. AAPG Bull., 62:40-72.

Fütterer, D. K., 1984. Bioturbation and trace fossils in deep sea sediments of the Walvis Ridge, Southeastern Atlantic, Leg 74. In Moore, T. C., Jr., Rabinowitz, P. D., et al., Init. Repts. DSDP, 74: Washington (U.S. Govt. Printing Office), 543-555.

Häntzchel, W., 1975. Trace fossils and problematica. In Teichert, C. (Ed.), Treatise on Invertebrate Paleontology. Part W, Suppl. 1, Miscellanea: Lawrence, KS (Univ. Kansas and Geol. Soc. Am), 1-269.

Haq, B. U., von Rad, U., O'Connell, S., et al., 1990. Proc. ODP, Init. Repts., 122: College Station, TX (Ocean Drilling Program).

Seilacher, A., 1967. Bathymetry of trace fossils. Mar. Geol., 5:413428.

Şengör, A.M.C., 1985. The story of Tethys: how many wives did Okeanos have? Episodes, 8:3-12.

Terry, R. D., and Chilingar, G. V., 1955. Summary of "Concerning some additional aids in studying sedimentary formations" by M. S. Shvetsov. J. Sediment. Petrol., 25:229-234.

von Rad, U., Thurow, J., Haq, B. U., Gradstein, F., Ludden, J., and ODP Leg 122/123 Shipboard Scientific Parties, 1989. Triassic to 
Cenozoic evolution of the NW Australian continental margin and the birth of the Indian Ocean (preliminary results of ODP Legs 122 and 123). Geol. Rundsch., 78:1189-1210.

Wetzel, A., 1987. Ichnofabrics in Eocene to Maestrichtian sediments from Deep Sea Drilling Project Site 605, off the New Jersey coast. In van Hinte, J. E., Wise, S. W., Jr., et al., Init. Repts. DSDP, 93 , Pt. 2: Washington (U.S. Govt. Printing Office), 825-835.

Wightman, D. M., Pemberton, S. G., and Singh, C., 1987. Depositional modelling of the Upper Mannville (Lower Cretaceous), East Central Alberta: implications for the recognition of brackish water deposits. In Tillman, R. W., and Weber, K. J. (Eds.), Reservoir Sedimentology. Spec. Publ. Soc. Econ. Paleontol. Mineral., 40:189-220.

Date of initial receipt: 13 June 1990

Date of acceptance: 8 April 1991

Ms 122B-170 


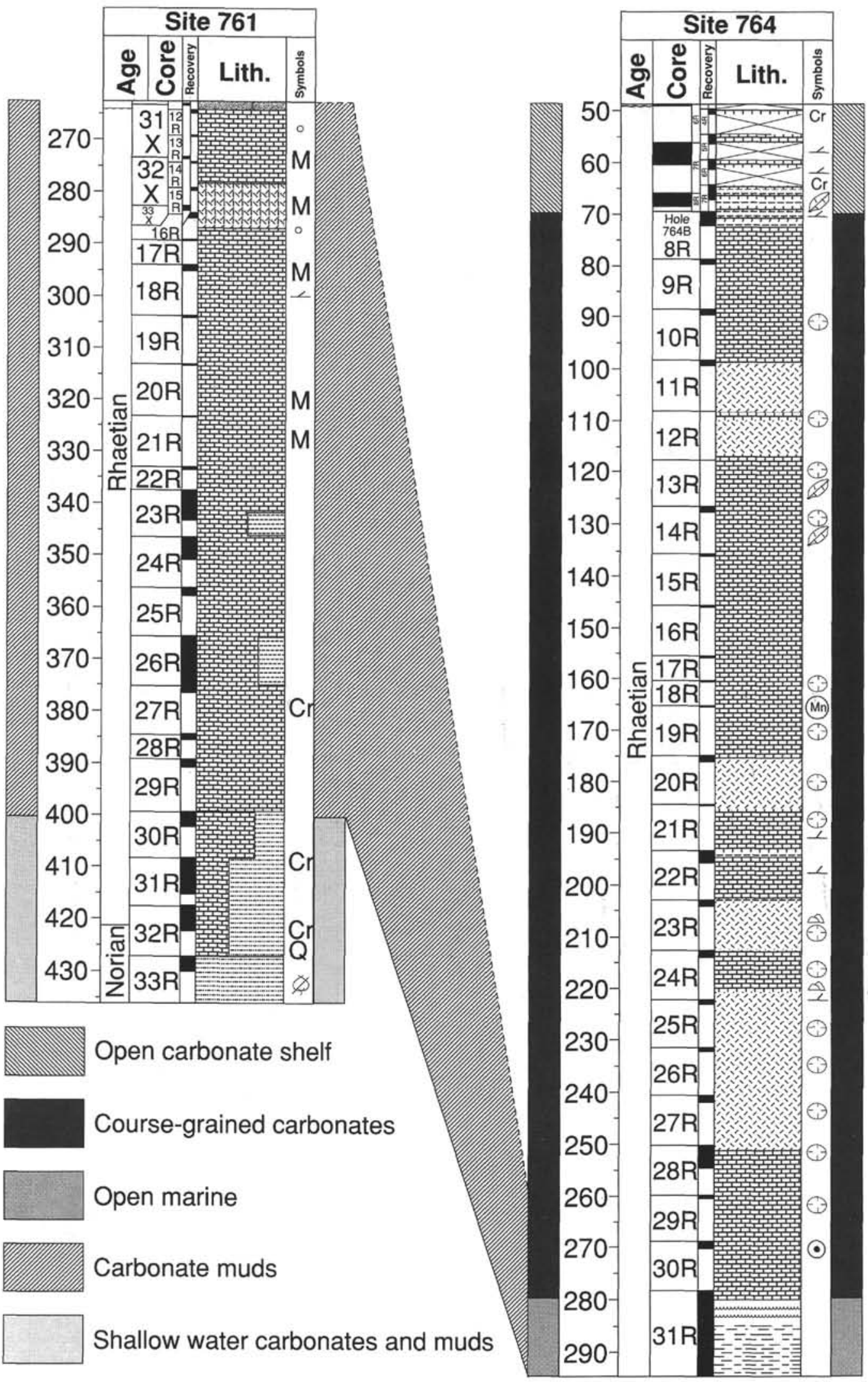

Figure 5. Correlation of facies described from Sites 761 and 764 based on sedimentological and ichnological characteristics. 


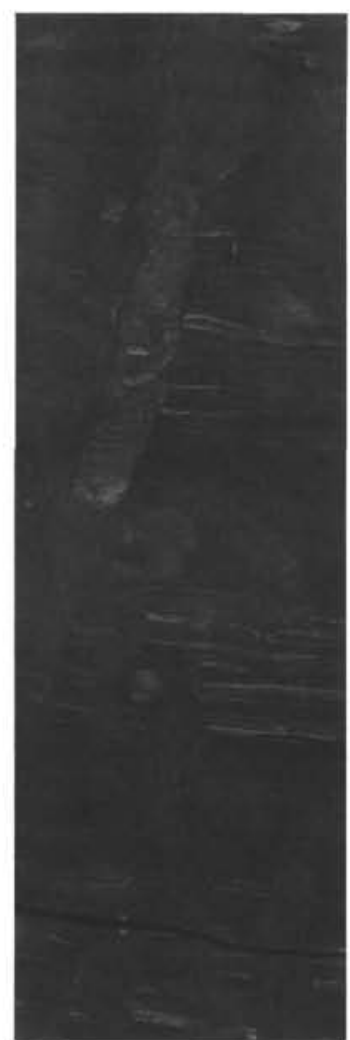

$$
1
$$

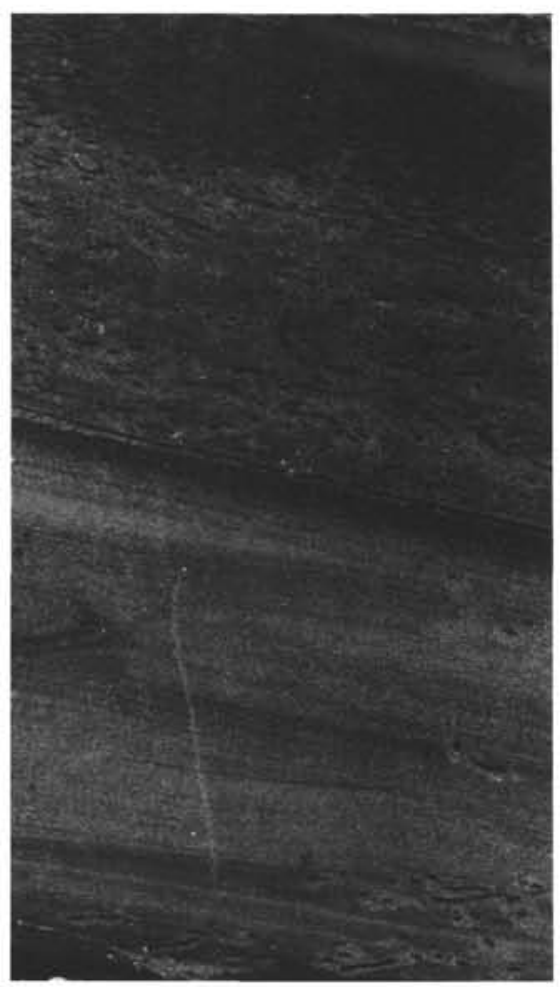

4

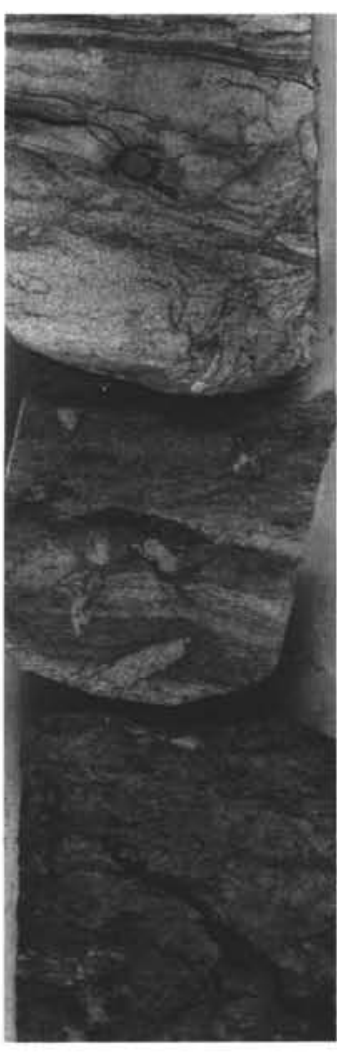

2
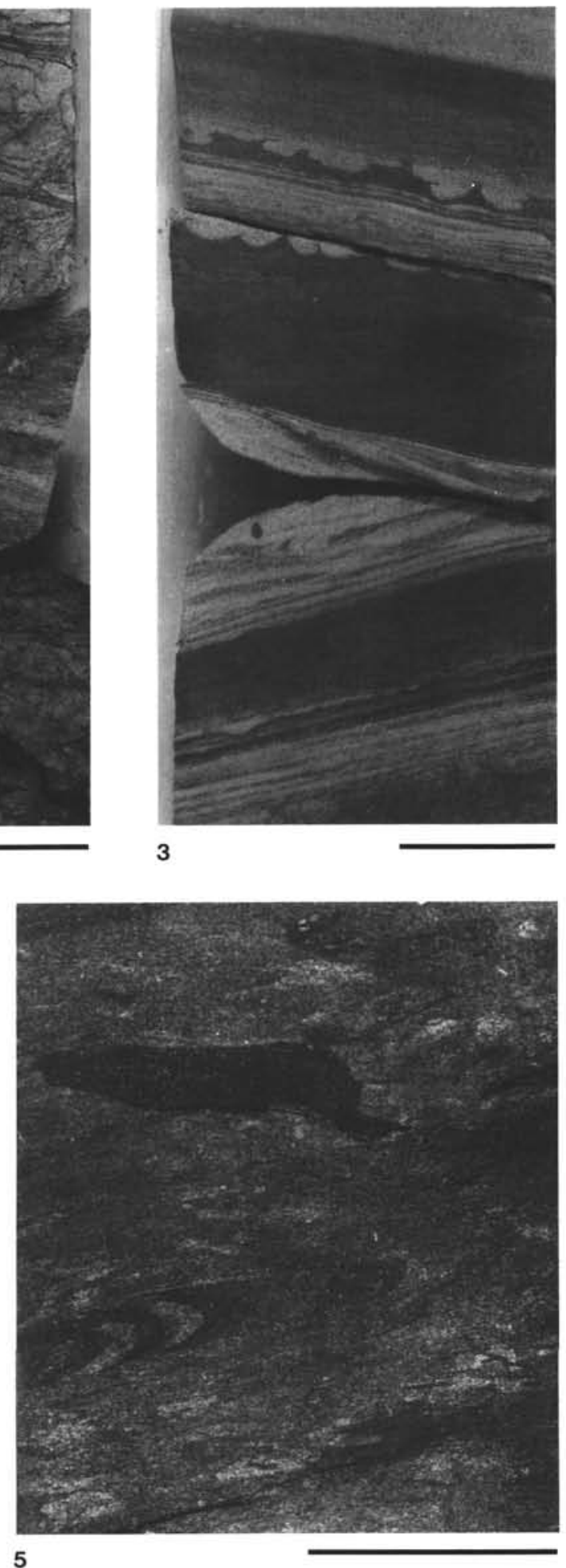

5

Plate 1. 1. An example of Teichichnus from Facies I, ichnofabric index 3. Scale bar $=5 \mathrm{~cm}$. Sample 122-760B-25R-2, 49-63 cm. 2. Transition from Facies I into Facies II. Scale bar $=5 \mathrm{~cm}$. Sample 122-760B-22R-2, 1-18 cm. 3. An example of Facies III (prodelta/delta front) sediments. Scale bar $=2 \mathrm{~cm}$. Sample 122-759B-32R-2, 17-29 cm. 4. An example of Chondrites in Facies III. Scale bar $=2 \mathrm{~cm}$. Sample 122-760B-23R-2, 22-30 cm. 5. Zoophycos in Facies VI. Ichnofabric index 5 . Scale bar $=2 \mathrm{~cm}$. Sample $122-764 \mathrm{~B}-31 \mathrm{R}-6,98-115 \mathrm{~cm}$. 


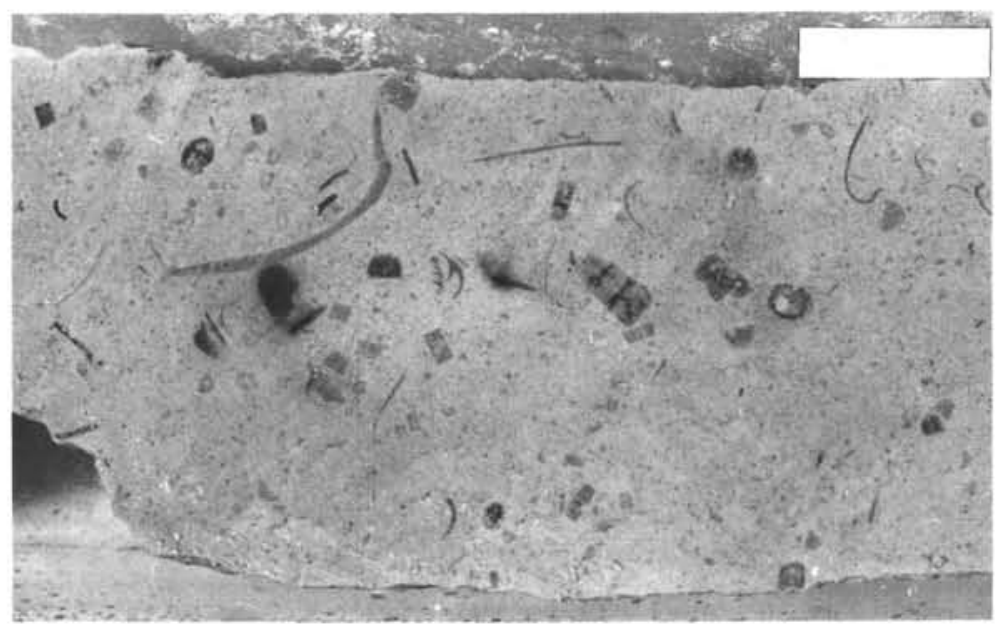

Plate 2. Coarse-grained carbonate strata of Facies $\mathrm{V}$ in which ichnofabric and discrete trace fossils are difficult to diagnose. Scale bar $=2 \mathrm{~cm}$. Sample 122-764B-4R-1, 48-58 cm. 